\title{
ФОРМУВАННЯ ВЛАСТИВОСТЕЙ НОВИХ ЗНОСОСТІЙКИХ ДЕТАЛЕЙ НА ОСНОВІ ВІДХОДІВ АЛЮМІНІЄВИХ СПЛАВІВ ДЛЯ ПОЛІГРАФІЧНИХ МАШИН
}

( ) Т. А. Роїк, д.т.н., професор, І. Є. Дорфман, аспірант, НТУУ «КПІ», Київ, Україна

\begin{abstract}
В статье представлены новые технологические методы получения композиционных антифрикционных материалов на основе отходов алюминиевых сплавов. Приведено сравнение физических, триботехнических и механических свойств композиционных антифрикционных материалов на основе отходов алюминиевых сплавов с литыми аналогами.
\end{abstract}

In the article new technological methods for obtaining composite antifriction materials based on aluminum-alloys wastes and comparing their tribotechnical, physical and mechanical properties of cast analogues, have been presented.

\section{Постановка проблеми}

Постійне підвищення якості поліграфічного обладнання, а саме вдосконалення роботи пари тертя є важливим завданням, оскільки саме від іх роботи залежить надійність, безвідмовність та довговічність поліграфічного обладнання в цілому [1]. Серед матеріалів контактних пар центральне місце займають матеріали тертьових сполучень, насамперед, антифрикційні матеріали. Це у повній мірі стосується підшипникових матеріалів, що працюють 3 мастилом у неважких умовах роботи (невисокі навантаження, швидкості ковзання, температури) [2-5].

\section{Аналіз попередніх}

\section{досліджень}

Інтерес до антифрикційних сплавів на основі алюмінію, що виготовлені методом порошкової металургії, неухильно зростає у зв'язку з іх суттєвими перевагами над литими ма- теріалами, такими як мала густина, висока корозійна стійкість, висока теплопровідність, питома міцність тощо та можливість введення до складу матеріалів широкого асортименту домішок, здатних надати матеріалу тих чи інших наперед заданих властивостей [5].

Вищезазначене свідчить про перспективність широкого застосування антифрикційних матеріалів на основі Al, проте існуючі технологічні складнощі у виготовлені зазначеного класу матеріалів та висока ціна вихідної сировини (порошків) та обладнання для ії виготовлення $є$ факторами, що обмежують використання композитів на основі Al.

Поряд з цим існуючі на сьогодні матеріали на основі алюмінію для різних умов роботи не задовольняють зростаючим потребам сучасної техніки, а саме: литі матеріали у ряді випадків мають недостатні показники триботехнічних властивос- 
тей, а порошкові, хоча й мають переваги перед литими, мають високу вартість. Водночас, в Україні існують великі джерела дешевої цінної сировини - це відходи кольорових та чорних металів та сплавів машинобудівного, металургійного, приладобудівного виробництв, які після переробки можна використовувати у подальшому виробничому циклі.

Тому питання створення нових антифрикційних матеріалів, що мають низьку густину, зокрема на основі алюмінію, та відрізняються високим рівнем функціональних властивостей, і при цьому $€$ не дорогими, $€$ вельми актуальним і потребує подальших досліджень.

\section{Мета роботи}

Метою роботи є встановлення впливу технологічних режимів одержання на формування структури і комплексу властивостей антифрикційних композиційних матеріалів на основі відходів алюмінієвого сплаву АК12ММгН призначених для роботи в неважких умовах експлуатації, а саме при температурах до 120 ॰ , швидкостях ковзання $1 \mathrm{~m} / \mathrm{c}$ і навантаженнях до 5 МПа на повітрі.

\section{Результати проведених досліджень}

Як основу підшипникових матеріалів для неважких умов експлуатації було обрано шламові відходи алюмінієвого сплаву АК12ММгН (відходами виробництва заводу «Київтрактородеталь», м. Київ), які утворюються при операціях шліфування деталей двигунів.
Складнолегований силумін АК12ММгН має у своєму складі велику кількість легувальних елементів [2], масова частка яких становить, \%: $\mathrm{Si}-11,0 \ldots 13,0, \mathrm{Cu}-1,2 \ldots 1,6$, $\mathrm{Mg}-0,9 \ldots 1,2, \mathrm{Zn}-0,3 \ldots 0,5$, $\mathrm{Sn}-0,01 \ldots 0,02, \mathrm{Mn}-0,3 \ldots 0,6$, $\mathrm{Cr}-0,05 \ldots 0,2, \mathrm{Ni}-0,8 \ldots 1,3$, $\mathrm{Na}-0,05 \ldots 0,1, \mathrm{Fe}-0,5 \ldots 0,8, \mathrm{~T}$ i $-0,05 \ldots 0,2$.

Набір цінних легувальних елементів у мікрочастинках порошків-відходів сплаву АК12ММгН є передумовою високого рівня триботехнічних, фізичних та фізико-механічних властивостей матеріалу.

Для можливості подальшого використання такої цінної сировини, колектив авторів [2, 4] розробив технологію регенерації цих порошків, що передбачає виконання двох стадій: висушення від вологи 3 відпалом компонентів мастильноохолоджувальної рідини (MOP) та сепаративне очищення від абразиву. Загальний вигляд частинок порошківвідходів сплаву АК12ММгН після регенерації представлений на рис. 1.

Bсе ширше набуває використання методів гарячого пресування для виготовлення антифрикційних матеріалів високої щільності. Цю методику було застосовано для відпрацьовування технології виготовлення матеріалів 3 відходів силуміну АК12ММгН [4-6].

Дослідні зразки з регенерованого силумінового шламу пресували у прес-формах різних типорозмірів:

1) у рознімній прес-формі розмірами $5 \times 40$ мм; 


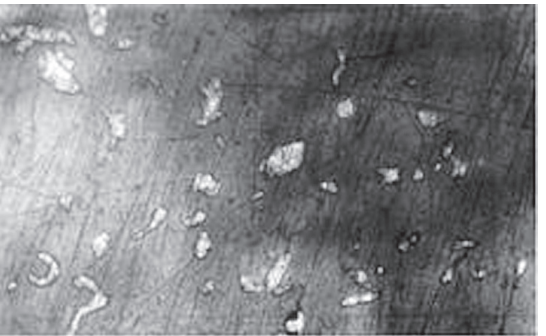

Рис. 1. Загальний вигляд частинок порошків-відходів сплаву

АК12ММгН після регенерації, $\times 32$ [5]

2) у втулковій прес-формі, розміри діаметра якої $32 \times 12$ мм;

3) у циліндричній прес-формі, розміри діаметра якої 32 мм.

Встановлено, що дослідні зразки, спресовані за питомого навантаження $500 \mathrm{MПа,} \mathrm{мають}$ такі значення відносної щільності відповідно для цих типорозмірів:

$1-0,88 \ldots 0,84$

$2-0,88 \ldots 0,89$;

$3-0,90 \ldots 0,92$.

Пресування виконували на гідравлічному пресі ПСУ-125. Після цього проводили операцію гарячого пресування попередньо спресованих зразків за температури зовнішнього нагрівання 400 оС та навантаження 300 МПа. Для уникнення припікання зразків до прес-

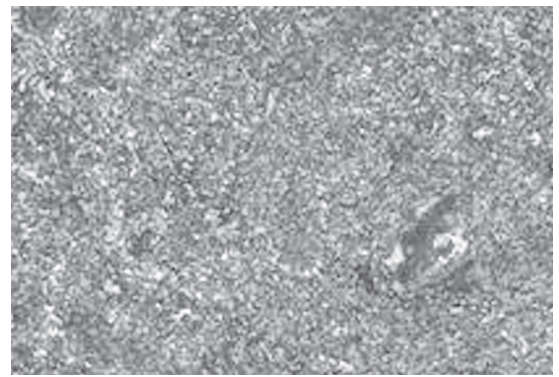

форми її змазували дисульфідом молібдену $\mathrm{MoS}_{2}$. Власне гаряче пресування проводили на гідравлічному пресі для гарячого пресування номінальним зусиллям 1,6 MH.

В результаті гарячого пресування відбувається формування складної гетерофазної металографічної структури матеріалу АК12ММгН. Вона складається 3 високолегованого $\alpha$-твердого розчину на основі алюмінію, в якому спостерігається присутність евтектики, що утворюється, як відомо, при вмісті кремнію 11,6 \% [2] та залягає за стільниковим малюнком зерен твердого розчину (рис. 2). Крім цього присутність великої кількості легуючих елементів спричинює утворення в структурі чималої частки дрібнодисперсних зміцнюючих фаз-інтерметалідів.

Мікроструктуру одержаного порошкового матеріалу АК12ММгН досліджували на аналізаторі зображення Leco IA3001 IMAGE SYSTEM (СШA) (рис. 3).

Структурні дослідження (рис. 3) свідчать, що наявні у матеріалі зміцнюючі фази (інтерметаліди) мають високу

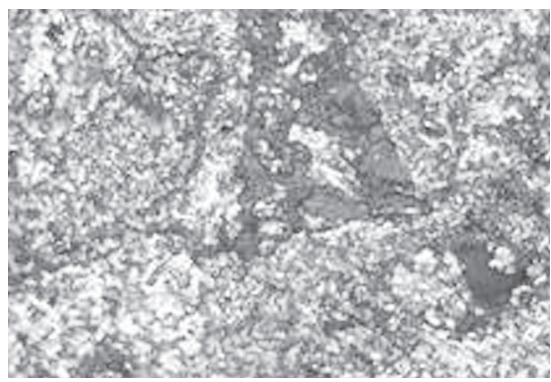

Рис. 2. Мікроструктура матеріалу зі шламових відходів сплаву AK12ММгН, при збільшенні $\times 100$ (а) та $\times 500$ (б) (шліф після травлення у 5 \% розчині $\mathrm{NaOH}$ ) 


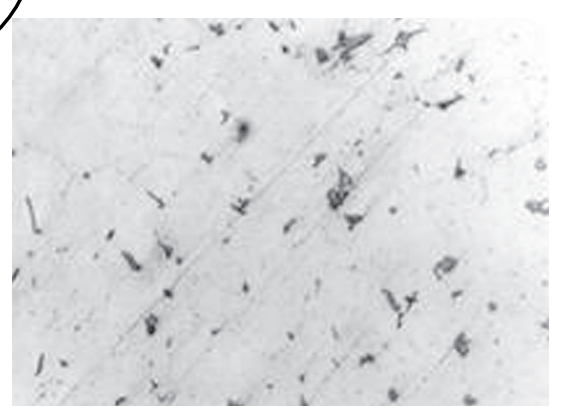

Рис. 3. Інтерметаліди в порошковому матеріалі АК12ММгН

густину та рівномірність розподілу за перерізом зразку, що сприяє зменшенню розміру зерна та, відповідно, підвищенню фізико-механічних та антифрикційних властивостей.

Триботехнічні характеристики у цьому дослідженні визначали за методикою високотемпературної трибометрії. У процесі випробувань на високотемпературній установці ВМТ-1 проводили автоматичний запис моментів тертя на діаграмний папір залежно від температури випробувань.

Випробування на тертя та знос проводили на повітрі при швидкості ковзання $1 \mathrm{~m} / \mathrm{c}$, навантаженнях до 5 МПа в парі 3 контртілом із сталі 45 (45-48 $\mathrm{HRC}_{\mathrm{e}}$ ), змащуванні мастилом «l-20» (для матеріалів AK12ММгH) і температурах зовнішнього нагріву $100-120^{\circ} \mathrm{C}$.

Значення властивостей композиційного матеріалу 3 відходів сплаву АК12ММгН у порівнянні з литим сплавом наведено у табл.

В табл. склад 1 - композиційний матеріал АК12ММгН, склад 2 - литий сплав АК12ММгН.

Аналіз даних табл. показує, що новий матеріал на основі відходів сплаву АК12ММгН за міцносними характеристиками не поступається литому сплаву [4], а за антифрикційними перевищує його. Така поведінка нового матеріалу криється в суттєвих відмінностях структуроутворення композиційного та литого сплаву АК12ММгН, що виникають внаслідок різних принципів синтезу матеріалів.

Вигляд поверхонь тертя зразка 3 матеріалу на основі відходів сплаву АК12ММгН та контртіла із сталі 45 зображено на рис. 4.

Сполучені поверхні ковзання пари тертя, що показані на рис. 4 відрізняються доброю якістю без ділянок сколів та гли-

Фізико-механічні та антифрикційні властивості матеріалів

\begin{tabular}{|c|c|c|c|c|c|c|c|c|}
\hline $\begin{array}{l}\text { Склад } \\
\text { мате- } \\
\text { ріалу }\end{array}$ & $\begin{array}{c}\text { Межа міц- } \\
\text { ності } \\
\text { на розтяг, } \\
\text { МПа }\end{array}$ & $\begin{array}{l}\text { Твер- } \\
\text { дість, } \\
\text { НВ, } \\
\text { МПа }\end{array}$ & $\begin{array}{l}\text { Ударна } \\
\text { в'яз- } \\
\text { кість, } \\
\text { КДж/м² }\end{array}$ & $\begin{array}{c}\text { Коефі- } \\
\text { цієнт } \\
\text { тертя }\end{array}$ & $\begin{array}{l}\text { Інтенсив- } \\
\text { ність зношу- } \\
\text { вання } \\
\text { зразка, } \\
\text { Мкм/Км }\end{array}$ & $\begin{array}{l}\text { Iнтенсив- } \\
\text { ність } \\
\text { зношу- } \\
\text { вання } \\
\text { контртіла, } \\
\text { мкм/км }\end{array}$ & $\begin{array}{c}\text { Гранич- } \\
\text { но до- } \\
\text { пус- } \\
\text { тима } \\
\text { темпе- } \\
\text { ратура, } \\
{ }^{\circ} \mathrm{C}\end{array}$ & $\begin{array}{c}\text { Гра- } \\
\text { нично } \\
\text { допу- } \\
\text { стиме } \\
\text { наван- } \\
\text { тажен- } \\
\text { ня, } \\
\text { МПа }\end{array}$ \\
\hline 1 & $180-185$ & $\begin{array}{l}550- \\
570\end{array}$ & $\begin{array}{c}0,18- \\
0,30\end{array}$ & $\begin{array}{l}0,0075- \\
0,0080^{*}\end{array}$ & $3,9^{*}$ & сліди & 120 & 6 \\
\hline 2 & 186 & 620 & $\begin{array}{c}0,30- \\
0,40\end{array}$ & $0,0250^{*}$ & $6,0^{*}$ & $2,5^{\star}$ & 120 & 3,5 \\
\hline
\end{tabular}

Примітка: *- випробування при 100 оС. При навантаженні 5 МПа. 

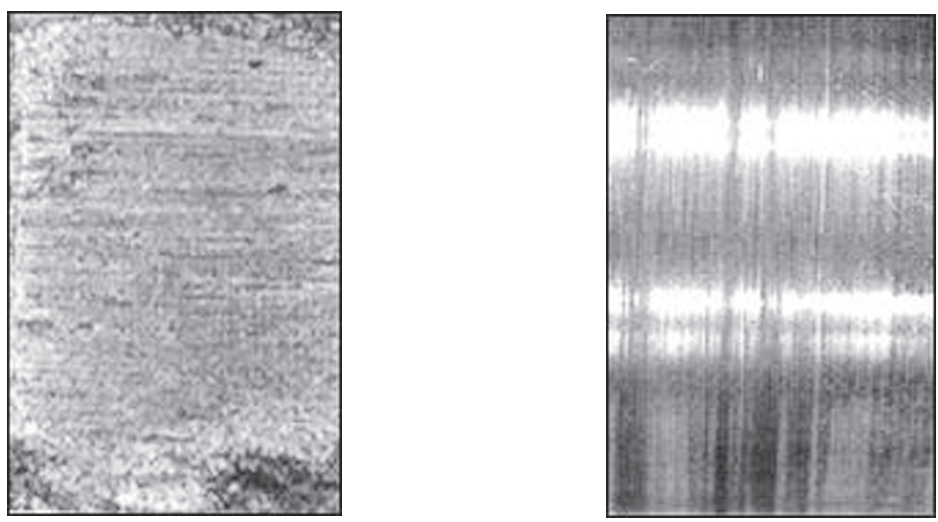

Рис. 4. Поверхні тертя зразка з матеріалу на основі відходів сплаву АК12ММгН (а) та контртіла із сталі 45 (б), ×5

бинних виривів. Топографія поверхонь матеріалів не має зон тужавлень та заїдань, що забезпечує стабільну і тривалу роботу антифрикційної пари.

Отже, наведені результати підтвердили вірність та доцільність застосованих принципів виготовлення композиційних підшипникових матеріалів, використовуючи у ролі вихідної сировини високолеговані цінні та одночасно дешеві шламові відходи алюмінієвого сплаву АК12ММгН.

\section{Висновки}

1. Дослідження показали, що в Україні існують великі потенційні сировинні джерела відходи кольорових та чорних металів і сплавів машинобудівного, металургійного, приладобудівного виробництв, які після певної переробки можна використовувати у подальшому виробничому циклі, що відповідає реалізації Програми розвитку ресурсозаощадних технологій.

2. На основі матеріалознавчого підходу одержано мож- ливість створювати вигідну, 3 точки зору тертя та зносу, гетерогенну структуру антифрикційних матеріалів на основі промислових відходів алюмінієвих сплавів та керувати нею для досягнення максимальних функціональних властивостей технологічними заходами - шляхом обирання вихідної сировини (порошків-відходів) необхідного хімічного складу та варіюванням параметрами одержання матеріалів.

3. Встановлено можливість отримання щільних дослідних зразків різних типорозмірів, 3 яких виготовляли натурні деталі методом гарячого пресування, що дозволило отримати вироби за властивостями, близькими до властивостей литого силуміну АК12ММгН.

4 При визначенні триботехнічних характеристик встановлено, що новий матеріал на основі відходів сплаву АК12ММгН за міцносними характеристиками не поступається литому сплаву. 
1. Поліграфічні матеріали. Підручник / Жидецький Ю. Ц., Лазаренко О. В., Лятошинська Н. Д., Маїк В. З., Мельников О. В., Олянишен Т. В., Румянцев Ю. М., Хаджинова С. Є., Якуцев С. / За заг. ред. д.т.н., проф. Е. Т. Лазаренка. - Львів : Афіша. - 2001. - 328 с. 2. Роїк Т. А. Вплив легуючих елементів на структуроутворення та властивості антифрикиійних матеріалів 3 силумінових відходів // Междунар. сб. науч. тр. «Прогрессивные технологии и системи машиностроения». - Донецк : ДонГТУ. - 2003. Вып. 26. - С. 44-51. 3. Пат. 34407 Україна, МКИ С 22С 21/02 Композиційний підшипниковий матеріал на основі алюмінію / Т. А. Роїк, А. П. Гавриш, О. Н. Гавриш, В. В. Холявко, О. М. Прохоренко. - № 200803173; Заявл. 12.03.2008; Опубл. 11.08.08, Бюл. № 15. - 3 с. 4. Новые композиционные материалы на основе алюминия / Ю. Ф. Шевчук, Т. А. Роик, В. П. Асанин, И. И. Белобородов // Вестн. НТУУ «КПИ». Машиностроение. - 1998. Вып. 33. - С. 209-213. 5. Роїк Т. А., Киричок П. О., Гавриш А. П. Композиційні підшипникові матеріали для підвищених умов експлуатації. - К. : НТУУ «КПІ», 2007. - 404 с. 6. Микрюков В. Е. Теплопроводность, электропроводность и механические свойства пористых железографитовых сплавов / В. Е. Микрюков, Н. З. Поздняк // Порошковая металлургия. - М. : Металлургиздат, 1984. - С. 37-72.

1. Poligrafichni materiali. Pidruchnik / Zhidets'kij Ju. Ts., Lazarenko O. V., Ljatoshins'ka N. D., Majyik V. Z., Mel'nikov O. V., Oljanishen T. V., Rumjantsev Ju. M., Hadzhinova S. Je., Jakutsevich S. / Za zah. red. d.t.n., prof. E. T. Lazarenka. - L'viv : Afisha. - 2001. - 328 s. 2. Rojyik T. A. Vpliv lehujuchih elementiv na strukturoutvorennja ta vlastivosti antifriktsijnih materialiv z siluminovih vidhodiv // Mezhdunar. sb. nauch. tr. «Prohressivnije tehnolohii i sistemi mashinostroenija». - Donetsk : DonHTU. - 2003. - Vip. 26. - S. 44-51. 3. Pat. 34407 Ukrajina, MKI S 22S 21/02 Kompozitsijnij pidshipnikovij material na osnovi aljuminiju / T. A. Rojik, A. P. Havrish, O. N. Havrish, V. V. Holjavko, O. M. Prohorenko. - № 200803173; Zajavl. 12.03.2008; Opubl. 11.08.08, Bjul. \# 15. - 3 s. 4. Novije kompozitsionnjije materialji na osnove aljuminija / Ju. F. Shevchuk, T. A. Roik, V. P. Asanin, I. I. Beloborodov // Vestn. NTUU «KPI». Mashinostroenije. - 1998. - Vjip. 33. - S. 209-213. 5. Rojik T. A., Kirichok P. O., Havrish A. P. Kompositsijni pidshipnikovi materiali dlja pidvishchenih umov ekspluatatsii. - K. : NTUU «KPI», 2007. - 404 s. 6. Mikrjukov V. E. Teploprovodnost', elektroprovodnost' i mehanicheskije svojstva poristih zhelezohrafitovih splavov / V. E. Mikrjukov, N. Z. Pozdnjak // Poroshkovaja metallurhija. - M. : Metallurhizdat, 1984. - S. 37-72.

Рецензент - А. П. Гавриш, д.т.н., професор, НТУУ «КПІ»

Надійшла до редакції 29.05.12 